\title{
Medievalista
}

Online

$25 \mid 2019$

Número 25

\section{Editorial: Política Científica, Financiamento, Internacionalização - Que cada um faça a sua parte}

\section{A Redacção}

\section{(2) OpenEdition}

\section{Journals}

\section{Edição electrónica}

URL: http://journals.openedition.org/medievalista/1724

DOI: 10.4000/medievalista. 1724

ISSN: 1646-740X

\section{Editora}

Instituto de Estudos Medievais - FCSH-UNL

\section{Refêrencia eletrónica}

A Redacção, « Editorial: Política Científıca, Financiamento, Internacionalização - Que cada um faça a sua parte », Medievalista [Online], 25 | 2019, posto online no dia 17 março 2019, consultado o 23 setembro 2020. URL : http://journals.openedition.org/medievalista/1724 ; DOI : https://doi.org/ 10.4000/medievalista. 1724

Este documento foi criado de forma automática no dia 23 setembro 2020.

Mediavalista está licenciado com uma Licença Creative Commons - Atribuição-NãoComercial 4.0 Internacional. 


\title{
Editorial: Política Científica, Financiamento, Internacionalização - Que cada um faça a sua parte
}

\author{
A Redacção
}

1 No momento em que este número 25 da Medievalista OnLine sai a público está em curso a última fase de avaliação das Unidades de Investigação Científica (UI's). Um processo longo, complexo, com acentuadas componentes burocráticas. Tudo a requerer um por vezes penoso desvio das suas actividades específicas por parte das UI's. Não está em causa a necessidade de uma avaliação externa, dirigida pela Fundação para a Ciência e a Tecnologia (FCT), às actividades e ao funcionamento dos Centros de Investigação tutelados por esta entidade. Uma política científica nacional rigorosa e a aplicação de financiamentos públicos, nacionais e comunitários, assim o exigem.

2 Mas tendo decorrido em 2014 um processo de avaliação cujos efeitos, em termos da aplicação de Projectos Estratégicos e de financiamento, se deveriam prolongar até 2020, não deixa de causar perplexidade o lançamento da nova avaliação que se tem prolongado há quase dois anos. É verdade que o anterior processo levantou inúmeros problemas, foi contestado por vários sectores e revelou sobejas anomalias. No nosso caso, o Instituto de Estudos Medievais (IEM) foi classificado com "Muito Bom", mas recebeu um financiamento inferior, em termos relativos, aos de outras UI's que não haviam conseguido passar com sucesso todas as etapas da avaliação... Não discutimos nem nos pronunciamos acerca de classificações alheias, mas não podemos deixar de constatar as incongruências.

Ora, havendo correcções a fazer e injustiças a colmatar, teria sido preferível e mais eficaz resolver os problemas pontuais anteriormente identificados, ouvindo reclamações e estabelecendo formas de eventual compensação nos casos em que tal se justificasse. Poderia repor-se a justiça, perder-se-ia menos tempo, não se massacrariam as UI's com a exigência de novos procedimentos administrativos que não correspondem à sua missão prioritária enquanto Centros de Investigação Científica. E poderia mesmo preparar-se, com tempo e em diálogo com a comunidade dos investigadores, um novo 
figurino de avaliação a concretizar depois de terminado o ciclo de Projectos Estratégicos em curso.

Além do mais, poupava-se dinheiro. Não se repetia, apenas três anos depois, o moroso e dispendioso percurso de contratação de numerosas equipas de avaliadores externos exclusivamente estrangeiros - com o que isso significa de pagamento de honorários, de viagens, de estadias em hotéis... Com essa economia poder-se-iam, por exemplo, corrigir ou, pelo menos, minorar as referidas injustiças criadas pela anterior avaliação. É verdade que o actual Governo afirmou desde a sua posse que iria lançar um novo modelo e um novo processo, que prometeu ser mais simplificado e menos burocrático. A repetição de um acto essencialmente administrativo que se arrasta no tempo, com custos na disponibilidade dos investigadores para o seu trabalho específico e com elevados gastos financeiros, revelou que aquela louvável intenção não passou de uma oportunidade perdida.

5 No que respeita à Medievalista, humana e financeiramente sustentada pelo IEM, fica-nos a expectativa - e a esperança! - de que a próxima classificação do Instituto e o correspondente financiamento por parte da FCT permitam fazer face às necessidades técnicas colocadas pelos cada vez mais exigentes requisitos de normalização e pela inclusão da revista em plataformas de indexação internacionais. A política de Ciência Aberta e de "Open Access" defendida pela Medievalista, pelo IEM e pela FCT também passa por aqui. Nós faremos a nossa parte.

É, aliás, o que continuamos a fazer, regularmente, com cada número da nossa revista. A presente edição conta com um importante Destaque: o estudo de Iria Gonçalves sobre "A Cozinha e a Mesa em Loulé Medieval nos seus Utensílios de Uso Comum: o Testemunho dos Inventários de Órfãos". Outros Artigos apresentam-nos trabalhos de William Trouvé sobre "El itinerário de una lista: de la Hispania visigoda a Italia beneventana, del Liber Iudiciorum al Pseudo-Isidoro", de Ana Luísa Sonsino um estudo sobre "Os Leitores do Espelho de Cristina: um Recorte das Cortes", de Lídia Amor um texto intitulado "Delectare ed prodesse: aventuras, placeres y didactismo en el Conte du Papegau" e de Mário Farelo o artigo "Roland Scriptoris ou de Lisbonne: un médecin, un professeur et un clerc portugais au XVe siècle". Na habitual secção de Recensões inclui-se uma da autoria de Filipe Alves Moreira sobre um recente livro de Carmen Benítez Guerreto, e outra de Pedro Chambel acerca do também recente livro colectivo editado por Francisco José Díaz Marcilla e José Higuera Rubio. A Apresentação de Teses informa-nos da dissertação de doutoramento de Manuel Fialho Silva sobre Mutação Urbana na Lisboa Medieval: das Taifas a D. Dinis, e da de mestrado de Marcelo Cardoso Amato acerca dos Simbolismos dos Animais com Chifres em Bestiários Ingleses, ambas defendidas no último ano. 0 número fecha com a Varia, que através de Ana Pagará e de Catarina Fernandes Barreira faz o balanço dos dois ciclos de conferências sobre manuscritos do Mosteiro de Alcobaça, contando ainda com a notícia de Clara Almagro Vidal sobre o workshop internacional "The Ties that Bind: Rethinking Dependences in the Medieval Iberian Peninsula and Beyond".

7 Uma última palavra acerca do próximo número, de Julho-Dezembro de 2019. Será uma edição temática sobre escultura românica, cujo dossier central é coordenado por Lucretia Kargère, conservadora do Metropolitan Museum, de Nova Iorque.

E é assim que a Medievalista vai fazendo a sua parte. 